\title{
PERANCANGAN LOGO DAN DESAIN KEMASAN COOKYE COOKIES SEBAGAI IDENTITAS VISUAL
}

\author{
Ervina Indah Permatasari' ${ }^{1}$, Sultan Arif Rahmadianto ${ }^{2}$, Ayyub Anshari Sukmaraga ${ }^{3}$ \\ Program Studi Desain Komunikasi Visual, Universitas Ma Chung \\ Email : 331810021@student.machung.ac.id, sultan.arif@machung.ac.id, \\ ayyub.anshari@machung.ac.id
}

\begin{abstract}
Abstrak
Sektor industri makanan \& minuman di Indonesia cukup banyak dan berkembang, Semakin berkembangnya jaman banyak pula bermunculan inovasi dalam pembuatan produksi makanan. Berbagai jenis makanan mulai dari makanan berat hingga makanan ringan sebagai pelengkap telah banyak melalui perkembangannya. Dessert merupakan salah satu makanan ringan yang cukup memiliki banyak varian rasa dan jenis seperti Cookye Cookies, dimana usaha rumahan ini memproduksi jenis kue kering dan soft cookies. Soft cookies yang diproduksi cukup unik dengan varian rasa yang ditawarkan, namun sebagai perusahaan makanan yang ingin berkembang Cookye Cookies belum memiliki identitas visual sebagai ciri dari perusahaannya. Perancangan untuk pembuatan logo, desain kemasan dan sosial media instagram karena era serba digital saat ini dapat membantu produk Cookye Cookies semakin dikenal oleh konsumen. Metode pengumpulan data dengan observasi dan wawancara, untuk metode perancangan dalam tugas mengunakan metode kualitatif, pada analisis data menggunakan teknik analisis SWOT. Perancangan digunakan agar data yang terkumpul digunakan sebagai acuan membuat konsep visual. Hasil akhir yang didapat berupa logo sebagai identitas visual, desain kemasan primer dan sekunder, foto untuk instagram, dan merchendise berupa tumbler, tote bag, dan $t$-shirt.
\end{abstract}

Kata kunci : logo, desain kemasan, digital, dessert

\begin{abstract}
The food \& beverage industry sector in Indonesia are quite numerous and growing. Along with the times there are many innovations in the manufacture of food production. Various types of food from heavy one onto snacks as a complement have been through its development. Dessert is one of the snacks that is quite a lot of flavors and types such as Cookye Cookies, where this home business produces types of pastries and soft cookies. The soft cookies that are produced are quite unique with the flavors offered, but as a food company that wants to develop, Cookies Cookies does not have a visual identity as a characteristic of the company. Designing the logo, packaging design and Instagram social media can help Cookye Cookies products to be increasingly recognized by consumers during this digital era. Methods of data by observation and interviews, for design methods in assignments using qualitative methods, in data analysis using SWOT analysis techniques. The design is used so that the data collected is used as a reference for making visual concepts. The final results are logos as visual identities, primary and secondary packaging designs, photos for Instagram, and merchandise such as tumblers, tote bags, and t-shirts.
\end{abstract}

Keywords : logo, packaging design, digital, dessert

\section{PENDAHULUAN}

UMKM merupakan jenis bisnis kecil yang dijalankan oleh perorangan dengan skala kecil dan menengah yang tidak menjadi anak perusahaan atau menjadi cabang perusahaan lain. Salah satu UMKM yang cukup menarik peminat adalah di sektor makanan dan minuman, karena memiliki beragam variasi dan inovasi dan dapat terus dikembangkan. Perkembangan kuliner di Indonesia dinilai cukup pesat, diliput dari data Asosiasi Perusahaan Jasa Boga (APJI) dalam sektor makanan dan minuman memberikan konstribusi sebanyak $12 \%$ pada tahun 2018 (Trihendrawan, 2019).

Kota Malang sebagai salah satu kota yang memiliki banyak UMKM sehingga pada tahun 2019 menerima penghargaan dalam bidang UMKM "Natamukti" dari International Council For Smart Bussines (ICSB)

(Firdausi, 2019). Dalam pembukaan Pucuk Coolinary Festival 2018 Wakil Wali Kota Malang, Bapak Sutiaji selaku Wali Kota Malang mengatakan bahwa kuliner termasuk subsektor yang sedang dikembangkan Badan Ekonomi Kreatif (BEKRAF). Bazar yang diadakan di Lapangan Rampal diikuti oleh 107 usaha kuliner yang berada di Malang Raya (Sasongko, 2018). Dari pernyataan tersebut dapat ditarik kesimpulan bahwa UMKM yang bergerak dalam sektor makanan dan minuman sangat banyak peminatnya di wilayah Kota Malang dan sekitarnya.

Dalam riset yang dilakukan Lembaga Demografi Fakultas Ekonomi dan Bisnis Universitas Indonesia, bahwa UMKM mengalami peningkatan dalam penjualan dengan adanya jasa pengiriman online, hasil riset yang telah dilakukan menunjukkan bahwa terjadi peningkatan penjualan sebanyak 26\% terhadap UMKM yang bergabung dengan Go-Jek. Pada tahun 2018 UMKM di sektor kuliner mengalami kenaikan hingga 50\% (Nurfadilah, 2018). Di tengah pandemi Covid-19 yang terjadi sepanjang tahun 2020 banyak UMKM yang terkena dampaknya, akan tetapi banyak pula pemilik UMKM yang melihat peluang ditengah pandemi ini, yaitu merubah bisnis penjualan mereka dari offline menjadi online dengan memakai jasa pengiriman online. Sehingga hal tersebut dapat membantu dalam bertahan dan meningkatkan penjualan di era pandemi ini. Sebagai salah satu usaha yang bergerak pada bidang makanan Cookye Cookies, yang lebih mengerucut kepada dessert atau makanan penutup berupa kue. Usaha yang sudah berdiri sejak 2008 merupakan usaha rumahan yang harus melalui pemesanan agar produk yang 
dihasilkan dari bahan yang masih fresh, usaha yang awalnya terbentuk karena sudah menjadi turun temurun kemudian lebih dikembangkan kembali pada tahun 2018 dengan melakukan beberapa inovasi dan kreasi baru dalam produksinya.

Kelebihan dari Cookye Cookies adalah pengunaan bahanbahan yang premium dan tanpa adanya bahan pengawet sehingga menghasilkan kue yang lezat serta kebersihan yang tetap terjaga, jika dibandingkan dengan UMKM lain Untuk harga jika dibandingakan dengan kompetitor lain lebih terjangkau sehinga Cookye Cookies dapat bersaing secara rasa dan kualitas. Pesanan akan dibuat secara fresh begitu pembeli melakukan pemesanan/ pre-order. Dengan begitu pembeli tidak perlu khawatir jika kue yang mereka pesan tidak cepat bas.Namun kelemahan dari Cookye Cookies ini kurangnya media promosi untuk mendukung penjualan produk karena saat ini di Kota Malang sendiri belum cukup dikenal, namun Cookye Cookies ditengah pandemi seperti ini sudah mengunakan kemajuan teknologi seperti Instagram sebagai media pendukung lainnya. Kelemahan lainnya terdapat pada pada logo dimana logo yang digunakan masih menggunakan font tanpa adanya elemen visual yang lain, serta desain kemasan yang masih kurang mendukung karena menggunakan kardus sebagai media kemasan dalam penjualan serta tidak adanya outlet atau toko untuk berjualan, sehingga masih mengandalkan penjualan online. Untuk meningkatkan penjualan mengunakan endorsment adalah pilihan yang tepat sehingga penjualan lebih terbantu dan produk lebih dikenal lagi. Cookye Cookies membuat produksi kue kering dan soft cookies. Awal pembuatan bisnis kue ini Cookye Cookies hanya menerima pesanan kue ketika momen tertentu, seperti hari raya maupun hari besar lainnya, namun ditengah pandemi seperti ini penjualan tidak hanya saat momen hari raya saja, lalu owner melakukan inovasi baru terhadap produknya dengan memproduksi soft cookies yang sedang trend saat ini agar tidak ketinggalan dengan banyaknya kompetitor kue yang lain. Cookye Cookies memiliki target konsumen menegah ke atas dikarenakan menggunakan bahan-bahan premium yang menjadi penentu harga. Segmen dari umur 17-40 tahun seperti mahasiswa atau keluarga yang ingin memberikan hampers pada momen tertentu seperti saat hari raya Idul Fitri maupun Natal dapat melakukan pemesanan. Cookye Cookies juga membuka pesananan setiap hari semenjak pandemi ini untuk meningkatkan penjualannya. Untuk masalah harga cukup variatif sesuai pesanan dan jenis kue

\section{TINJAUAN PUSTAKA}

Mukhtar dan Nurif (2015) dalam judul "Peranan Packaging Dalam Meningkatkan Hasil Produksi Terhadap Konsumen" tujuan perancangan ini adalah memberikan pengertian tentang faktor-faktor dalam desain kemasan, fungsi dari sebuah kemasan, ragam dari kemasan, dan desain kemasan sebagai media komunikasi dan informasi. Dalam artikel ilmiah ini menjelaskan manfaat suatu produk kemasan dan fungsifungsi dari kemasan yang diproduksi yang dapat digunakan sebagai acuan dalam menciptakan produk kemasan nantinya.

Mufreni (2016) dalam judul "Pengaruh Desain Produk Bentuk Kemasan Dari Bahan Kemasan Terhadap Minat

Beli Konsumen, Studi Kasus Teh Hijau Serbuk Tocha" dalam artikel ini menjelaskan bagaimana kemasan mampu menjadi pemicu dalam penjualan produk serta pemilihan warna yang mempengaruhi persepsi menegnai kegunaan suatu produk. Referensi yang didapat dalam artikel ini dapat memberi masukan bahwa pemilihan warna sangatlah berpengaruh dan pemilihan teks yang dapat merubah perspektif konsumen. Christy dan Ellyawati (2014) dalam judul "Pengaruh Desain Kemasan (Packaging) Pada Impulsive Buying" tujuan pada perancangan jurnal ilmiah ini adalah tidak terdapat perbedaan terhadap penilaian konsumen pada variabel terhadap desain kemasan (desain grafis, struktur desain, dan informasi produk) serta impulsive buying berdasarkan perbedaan jenis kelamin. Sehingga dijelaskan bahwa konsumen pria maupun wanita dengan rentang usia yang berbeda memiliki penilaian yang sama terhadap desain kemasan. Referensi yang didapat didapatkan informasi pengumpulan data bahwa yang mempengaruhi minat seorang dalam kemasan ialah struktur yang terdapat dalam kemasan tersebut, serta gender tidak menentukan minat terhadap suatu kemasan. Prawita, dkk (2017) dengan judul "Membangun Identitas Visual Untuk Media Promosi Usaha Mikro Kecil dan Menengah"),tujuan dari jurnal ilmiah ini adalah untuk membangun identitas visual pada produk yang dihasilkan untuk mampu bersaing dengan kompetitor lainnya, dengan hasil. Dari jurnal ilmiah terkait didapatkan informasi mengenai perancangan pentingnya mengembangkan identitas perusahaan untuk meningkatkan penjualan dan meningkatkan daya tarik konsumen, serta peran media promosi dalam mempengaruhi konsumen.

Atsar (2014) dengan judul "Persepsi dan Citra Identitas Visual Bank Mandiri" tujuan dari penelitian ini adalah untuk memperoleh sudut citra dan persepsi logo Bank Mandiri,logo sebagai identitas visual berperan penting dalam memperlihatkan dan mengekspresikan visi dan misi perusahaan terhadap masyarakat umum, setiap elemen dalam logo sebagai identitas visual perusahaan menimbulkan respon dan persepsi terhadap stakeholder atau pelanggan. Dari jurnal ilmiah tersebut perancangan mendapat masukan dengan menggunakan penelitian untuk logo menggunakan metode deskriptif kualitatif sebagai salah satu metode mendapatkan hasil penelitian.

\section{METODE PERANCANGAN}

Metode yang digunakan dalam perancangan ini ialah dengan metode kualitatif yang bertujuan untuk melakukan penjelasan, penelitian, penggambaran dari pengaruh sosial. Metode kualitatif lebih menekankan pada fenomena dan lebih meneliti makna dari sebuah fenomena tersebut. Untuk metode pengumpulan data menggunakan observasi dan wawancara. Observasi dengan datang langsung ke tempat 
produksi untuk melihat proses pembuatan, serta sumber daya manusia yang ikut dalam proses produksi. Wawancara kegiatan tanya jawab yang dilakukan secara langsung terhadap produsen dari Cookye Cookies untuk melihat permasalahan. Berdasarkan pengumpulan data di atas, diapat diperoleh melalui penerapan metode analisis berupa $5 \mathrm{~W}+1 \mathrm{H}$. Metode tersebut dapat menjawab permasalahan produk Cookye Cookies dan dapat melakukan penelitian untuk membuat konsep untuk meningkatkan penjualan dan daya tarik. Setelah data terkumpul dibuatlah konsep visualisasi dengan menentukan thumbnail kemudian membuat roughsketch kemudian final dan dapat diterapkan pada media sebagai brand awareness.

\section{Tabel 1. Analisis SWOT}

\begin{tabular}{|c|c|c|}
\hline & Strenghts & Weakness \\
\hline$\frac{\tilde{z}}{\tilde{E}}$ & $\begin{array}{c}\text { ST } \\
\text { Memanfaatkan potensi } \\
\text { menghadapi ancaman }\end{array}$ & $\begin{array}{c}\text { WT } \\
\text { Meminimalkan kelemahan } \\
\text { untuk menghadapi ancaman }\end{array}$ \\
\hline 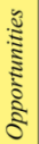 & $\begin{array}{c}\text { SO } \\
\text { Memanfaatkan potensi } \\
\text { untuk meraih peluang }\end{array}$ & $\begin{array}{c}\text { WO } \\
\text { Mengatasasi kelemahan } \\
\text { untuk meraih peluang. }\end{array}$ \\
\hline
\end{tabular}

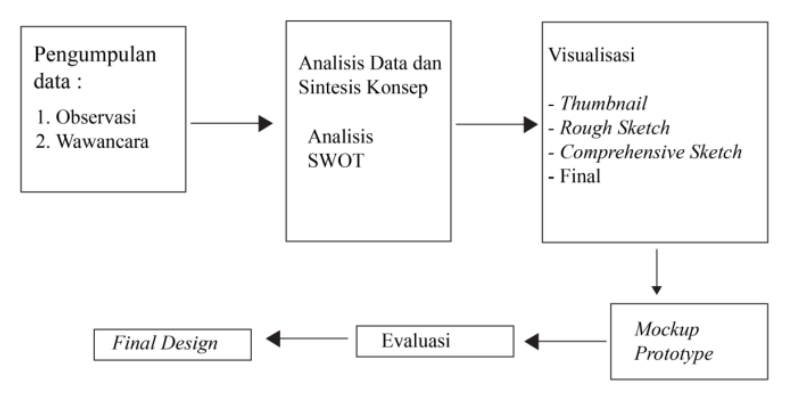

Gambar 1. Bagan Alir Perancangan

\section{HASIL DAN PEMBAHASAN}

\subsection{Pengumpulan dan Analisis Data}

Untuk merancang logo serta media promosi Cookye Cookies dibutuhkan informasi mengenai perusahaan serta produk yang dijual. Informasi yang didapat tersebut diperlukan sebagai dasar untuk menentukan strategi dalam bentuk visualisasi dan promosi. Melalui pengumpulan data tersebut dapat diketahui bagaimana pesan yang ingin disampaikan terhadap calon konsumen Cookye Cookies melalui brand identity yang telah dirancang. Brand identity memiliki peran penting terhadap penjualan suatu produk dimana dirancang agar dapat menyampaikan pesan kepada konsumen serta dapat digunakan sebagai pemecah masalah dalam proses pengembangan produk.

\subsection{Analisa Data}

Analisis data dengan mengunakan metode SWOT dilakukan untuk penelitian terhadap lingkup internal perusahaann Cookye Cookies dan pada lingkup eksternal terhadap kompetitor sejenis dan peluang yang dimiliki oleh Cokkye Cookies sehingga dapat digunakan sebagai landasan untuk mengembangkan proses produksi dan penjualan Cookye Cookies. Hasil yang didapat dalam analisis SWOT untuk menentukan kekuatan (strength) pada Cookye Cookies, untuk menemukan kelemahan (weakness) pada produk. Peluang (oppotunity) dengan penggunaan logo serta kemasan yang baru dapat meningkatkan penjualan, serta tingkat kepercayaan konsumen terhadap produk dapat lebih meningkat. Ancaman (threads)Ancaman yang diperoleh terhadap Cookye Cookies banyaknya perusahaan serupa yang juga memproduksi soft cookies memiliki desain visual terhadap kemasan. Kompetitor menawarkan harga yang lebih murah dibanding Cookye Cookies. Berdasarkan hasil analisis dengan metode SWOT diatas, diharapkan dalam proses perancangan ini dapat mengatasi kelemahan yang terdapat pada perusahaan Cookye Cookies dan menjadikannya sebagai kekuatan, serta cara dalam mengatasi ancaman dari kompetitor sehingga produk mampu bersaing dan peluang dapat lebih ditingkatkan dalam berbagai aspek.

4.3 Sintesis Konsep Perancangan Setelah mengumpulkan data melalui analisis yang dilakukan secara observasi, wawancara, maupun analisis SWOT, ditemukan permasalahan yang dialami oleh perusahaan Cookye Cookies ialah terdapat pada brand identity yang saat ini belum sesuai, visualisasi pada kemasan yang dianggap tidak menarik, serta banyaknya kompetitor serupa yang mulai banyak melakukan inovasi dalam promosinya. Sehingga Cookye Cookies harus membentuk brand identity agar mampu mencapai segmen target pemasaran. Sintesis konsep dari perancangan ini berupa konsep media/brief menggunakan konsep dengan gaya desain minimalis sehingga desain yang dihasilkan dapat terlihat simple namun tetap memiliki kesan elegan. Gaya desain yang mampu mencerminkan kualitas produk ini. Konsep visualisasi tersebut akan diterapkan pada pembuatan logo, buku Graphic standard Manual (GSM), perancangan pada desain kemasan serta beberapa merchandise yang berkaitan dengan produk Cookye Cookies.

Tujuan utama dalam pembuatan media ini adalah untuk memecahkan permasalahan yang selama ini dihadapi oleh perusahaan Cookye Cookies yaitu dengan meningkatkan fungsi pada kemasan, brand identity yang kuat serta peraan media promosi dalam meningkatkan penjualan.

Strategi desain dilakukan dengan instagram sebagai media promosi online. Sosial media saat ini merupakan cara yang cukup efektif untuk mempromosikan suatu produk dijaman milenial saat ini dengan banyaknya pengguna dapat dimanfaatkan sebagai salah satu media menjual produk. Kemasan Cookye Cookies juga sebagai salah satu media promosi yang secara tidak langsung sebagai alat visualisasi logo yang diterapkan.

Dalam perancangan media diutamakan pada pembuatan logo dan desain kemasan. Cookye Cookies membutuhkan perubahan pada logo serta kemasan, lalu pembuatan Graphic standard Manual (GSM) sebagai pedoman untuk 
mendasari pembuatan logo. Perancangan kreatif dilakukan untuk mengenalkan brand identity sebagai identitas visual yang dimiliki Cookye Cookies, visual yang akan ditampilkan ialah dengan foto produk sebagai media promosi pendukung untuk menarik minat konsumen.

Perancangan desain dirancang sesuai dengan target audiens dari Cookye Cokies. Media promosi pada instagram akan menampilkan foto produk yang merupakan hal paling utama yang dilakukan untuk menjual produk.Karena minat beli konsumen adalah sesuatu yang timbul setelah menerima rangsangan pada produk yang dilihat dan dari situlah muncul ketertarikan mencoba dan membeli suatu produk.

\section{.HASIL}

\section{Visualisasi Desain}

Perancang identitas visual dan media promosi Cookye Cookies melalui beberapa tahapan yaitu dengan perancangan logo, kemudian perancangan buku Corporate Identity System serta mengaplikasikan pada merchandise dan perancangan sosial media Instagram sebagai media promosi. Tahap pertama yang dilakukan penulis ialah pembuatan sketsa logo yang kemudian dilakukan beberapa revisi dan masukan yang telah didapatkan. Setelah logo terpilih dikerjakan dalam bentuk digital dengan menggunakan software Adobe Ilustrator. Logo telah selesai dibuat dalam bentuk digital dilakukan pemilihan color palette yang sesuai dengan karakter perusahaan serta tujuan perusahaan. Setelah proses pembuatan logo dengan warna yang telah terpilih dibuatlah buku Corporate Identity System dimana buku ini dibuat dengan tujuan mengatur pengunaan logo untuk kedepannya sehingga dapat diterapkan pada media yang sesuai. Hal ini sangat diperlukan agar menjaga konsistensi penggunaan logo agar lebih teratur.

Setelah disusunnya buku Corporate Identity System dapat dilanjutkan pada perancangan berikutnya yaitu perancangan desain kemasan Cookye Cookies. Perancangan desain kemasan dilakukan pada 2 jenis kemasan yaitu kemasan primer dan sekunder pada kemasan primer dibutuhkan 2 jenis ukuran untuk kemasan paket. Pembuatan kemasan menggunakan grid agar tertata dan ukuran sesuai dengan yang

diperhitungkan

Pada tahap thumbnail dilakukan eksplorasi berbagai logo untuk terpilih logo yang mewakili konsep Cookye Cookies. Sehingga dapat drealisasikan dengan menyatukan ide sehingga dapat dilanjutkan pada tahap rough sketch.

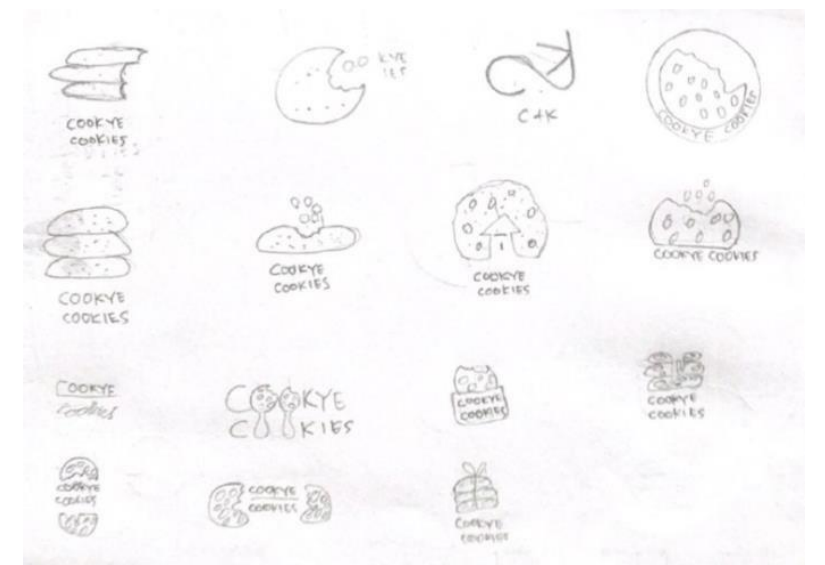

Gambar 2. Thumbnail

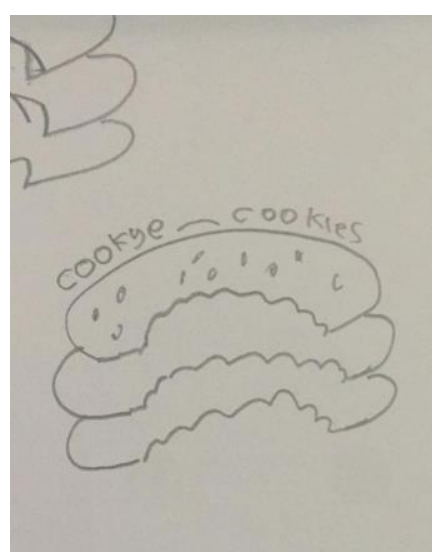

Gambar 3. Thumbnail Logo

Perancangan logo rough sketch yang dikerjakan merupakan tahap dari merealisasikan ide dan konsep yang sudah dikembangkan yang mengandung makna dari pada perusahaan. Pada rancangan rough sketch merealisasikan dari ide-ide sebelumnya pada thumbnail. Kemdian dikerucutkan menjadi bentuk cookies dengan adanya bekas gigitan dibeberapa sisi.
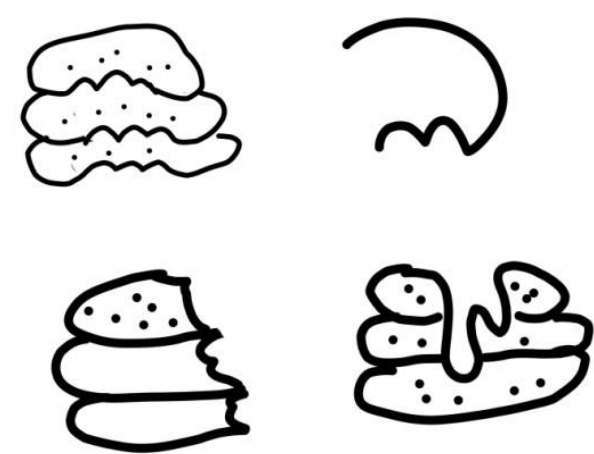

Gambar 4. Logo Rough Sketch 


\subsection{Logo}

Comprehensive terpilih satu logo yang sesuai dengan makna serta latar belakang dan tujuan yang ingin disampaikan kepada konsumen, kemudian dilakukan penyempurnaan dengan sistem grid. Logo memiliki bentuk cookies yang bertumpuk tiga kemudian terdapat bekas gigitan pada setiap cookies. Konsep ini diambil diambil bahwa produk ini begitu lezat sehingga tidak cukup hanya memakan satu saja sehingga tiga cookies yang tertumpuk memiliki bekas gigitan.

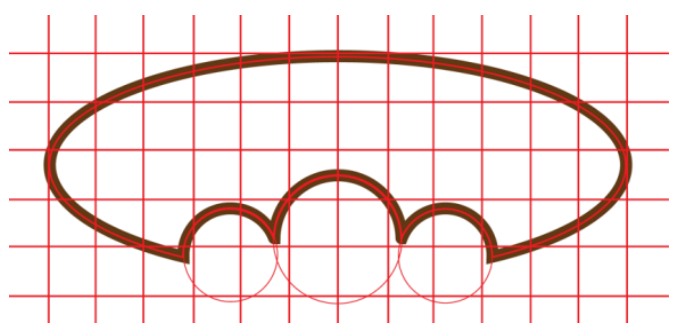

Gambar 5. Konsep Logo Grid

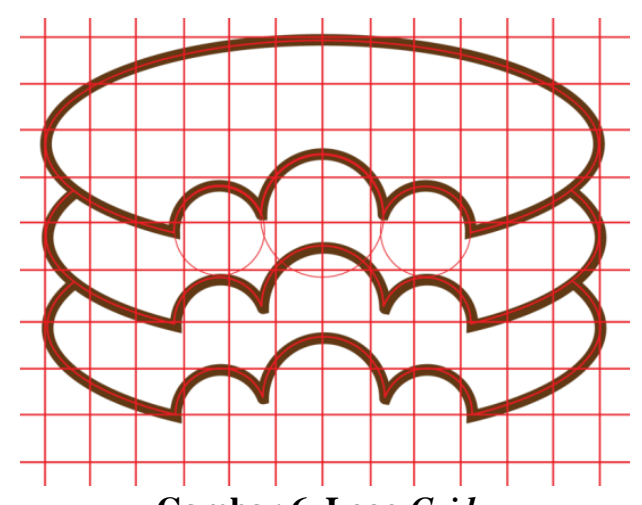

Gambar 6. Logo Grid

Logogram yang telah terpilih sebelumnya kemudian dilengkapi dengan logotype untuk identitas Cookye Cookies. Logotype memiliki peran untuk menerangkan para konsumen untuk dapat mengenali produk sehingga menerengakan nama produk.

\section{Cookye Cookies}

Gambar 7. Logotype Grid

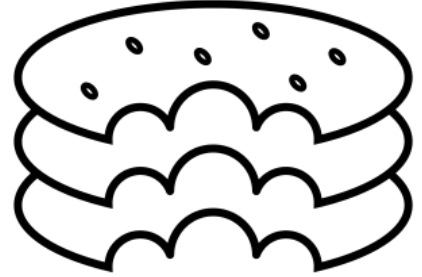

\section{Cookye Cookies}

Gambar 8. Logo Final dan Logotype

Cookye Cookies menggunakan turunan dari warna cokelat sebagai warna utama dan warna pada kemasan. Karena warna cokelat merupakan warna pada umumnya cookies, kemudian warna cokelat sendiri merupakan warna organik karena sebagai warna bumi yang memiliki kesan alami karena produk cookies yang dihasilkan alami dengan bahan bagus tanpa adanya pengawet makanan sehingga aman. warna cokelat juga memberikan kesan hangat, nyaman dan ramah. Palet warna diterapkan dalam logo, pattern, packaging, serta media lainnya.
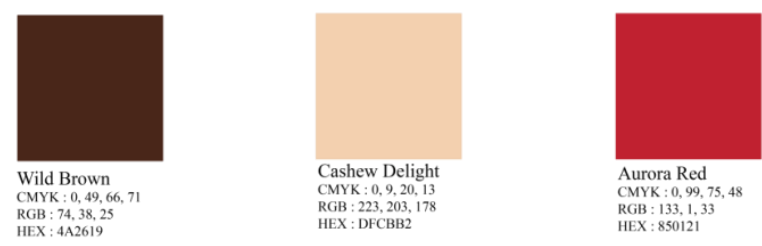

Gambar 9. Color Palete
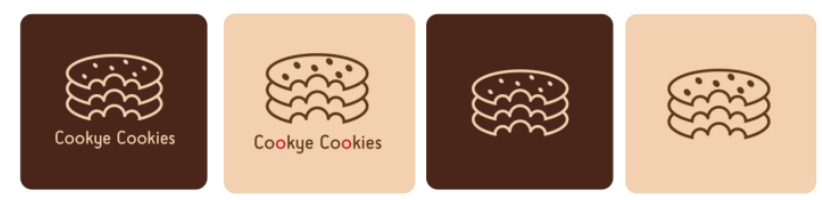

Gambar 10. Penerapan Logo

Pattern kemasan merupakan salah satu penunjang bagaimana produk tersebut dapat dikenali dengan mudah oleh konsumen, kemudian pada kemasan ditambahkan pattern untuk mengisi ruang kosong. Pattern yang digunakan diambil dari bentuk logo yang sudah ada kemudian diolah agar dapat menjadi identitas visual yang dapat dengan mudah dikenali.

Setelah mengumpulkan beberapa makna untuk dirancang kemudian muncullah pola garis horisontal yang memiliki kesan statis, tenang. Kemudian pattern kedua yang diambil dari bagian bentuk logo yang berbentuk seperti bekas gigitan pada cookies, sehingga diharapkan para konsumen tetap menjadikan produk Cookye Cookies sebagai satusatunya dessert yang dipilih dan tetap menjadi konsumen setia yang tidak berpindah ke produk lain. 


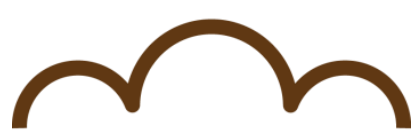

Gambar 11. Pattern Logo

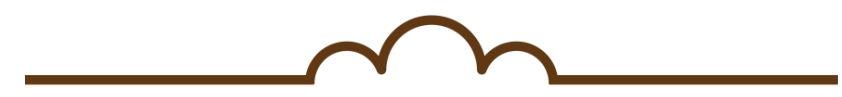

Gambar 12. Comprehensive Pattern

\subsection{Kemasan}

Kemasan merupakan hal sangat penting dalam sebuah branding dimana setiap pemilik usaha tentu ingin memiliki brand awareness yang menarik di mata para konsumen. Bentuk dan desain kemasan yang menarik merupakan hal yang sangat digemari oleh konsumen dimana kemasan yang telah digunakan dapat digunakan kembali, kemasan merupakan bagian terluar yang membungkus sebuah produk dimana berfungsi untuk melindungi sebuah produk. Sisi ergonomis juga diperlukan dalam pembuatan suatu kemasan sehingga pada bentuk desain kemasan terdapat handler pada bagian atas box sehingga mudah dibawa. Terdapat juga kemasan kotak yang digunakan sebagai kemasan primer karena langsung bersentuhan dengan produk, serta paper bag sebagai pelindung kedua.

\section{Gambar 16. Kemasan Primer}

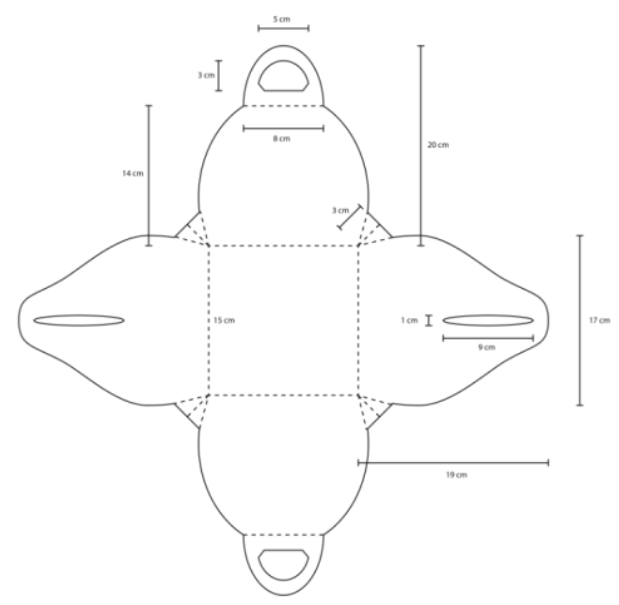

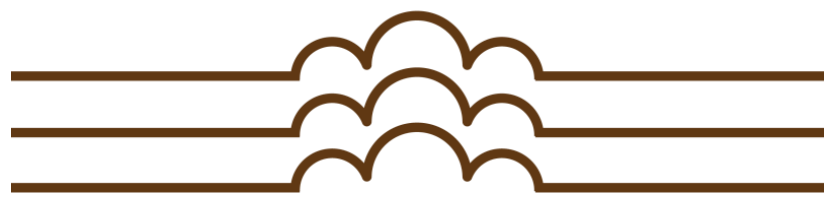

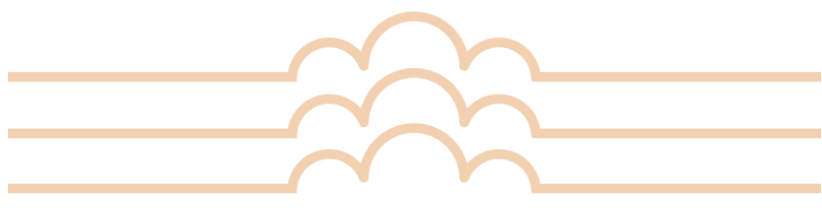

Gambar 13. Final Pattern

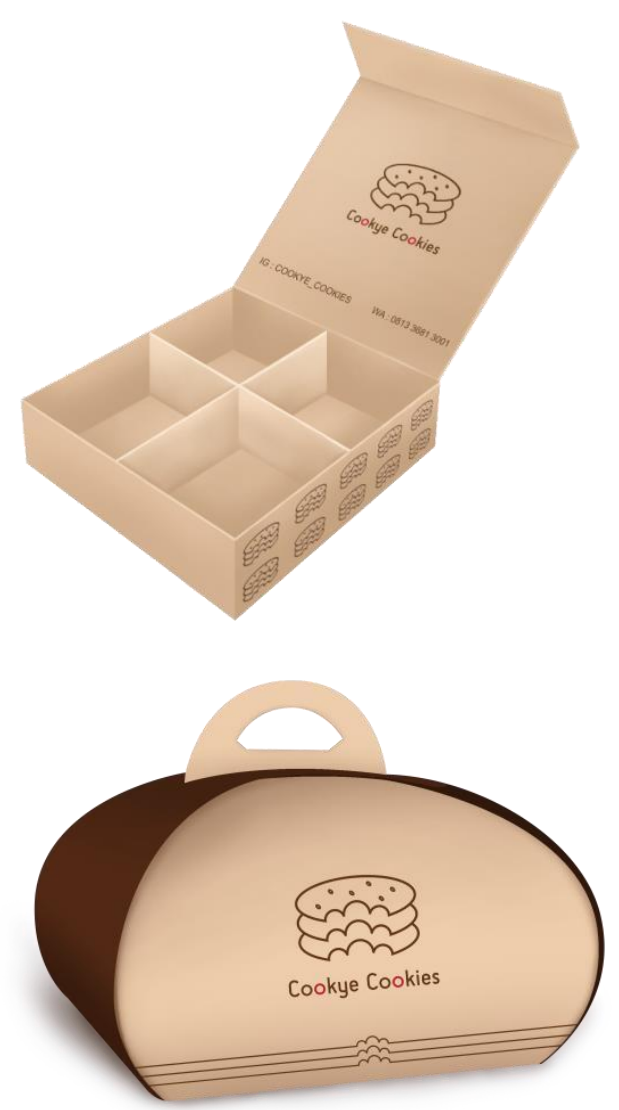

Gambar 17. Kemasan Sekunder 


\section{Gambar 14. Pola Kemasan Sekunder}

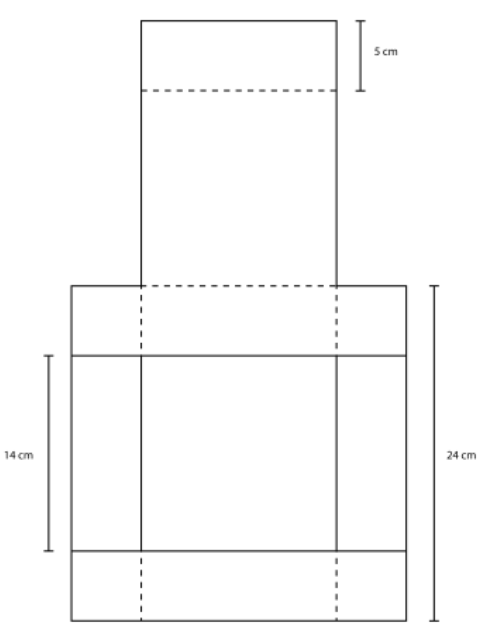

Gambar 15. Pola Kemasan Primer

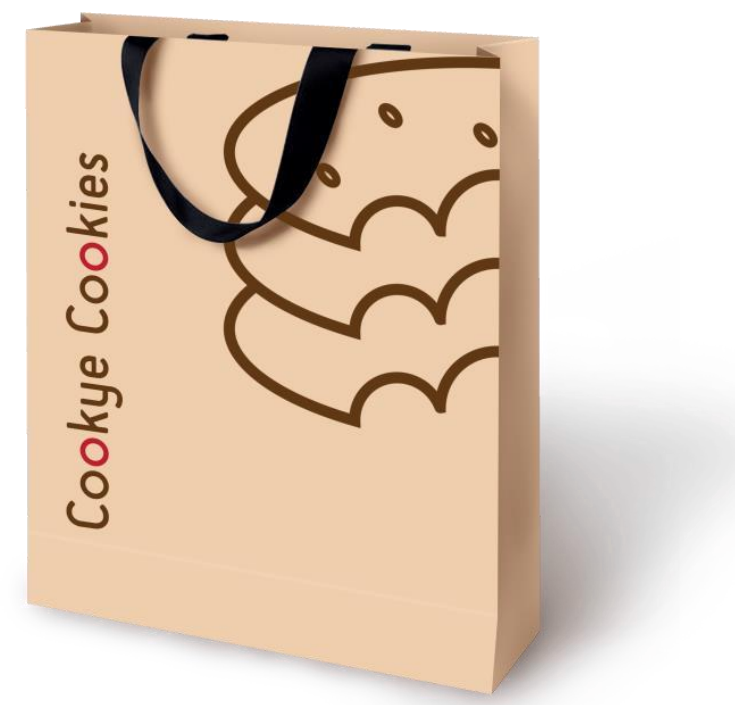

Gambar 18. Paper Bag

\subsection{Corporate Identity System}

Buku CIS memiliki fungsi sebagai panduan dalam menerapkan logo pada media sehingga menghindari penggunaan yang salah, karena identitas visual merupakan hal yang cukup penting. Tujuan dibuatnya buku ini untuk mempertahankan konsistensi penggunaan logo diberbagai macam media pendukung. Sehingga identitas Cookye Cookies tidak berubah dan dapat mudah diingat dan dikenali oleh konsumen.

Tabel 2. Corporate Identity System

\begin{tabular}{|c|c|c|}
\hline Halaman & Judul & Keterangan \\
\hline 0 & Table Of Content & Daftar isi \\
\hline 1 & Lookye Cookies & Tentang perusahaan \\
\hline 3 & Logo Elements & Penjelasan logo \\
\hline 4 & $\begin{array}{c}\text { Logo } \\
\text { Configuration }\end{array}$ & $\begin{array}{c}\text { Gabungan antara } \\
\text { logogram dan logotype }\end{array}$ \\
\hline 5 & $\begin{array}{c}\text { Logo Size } \\
\text { Restriction }\end{array}$ & $\begin{array}{c}\text { Ukuran minimum logo } \\
\text { Logo Construction }\end{array}$ \\
\hline 6 & $\begin{array}{c}\text { Grid dalam proses } \\
\text { pembuatan logo }\end{array}$ \\
\hline
\end{tabular}

\begin{tabular}{|c|c|c|}
\hline $7-9$ & Logo Usage & Penerapan logo \\
\hline 10 & $\begin{array}{c}\text { Incorrect Logo } \\
\text { Usage }\end{array}$ & $\begin{array}{c}\text { Penerapan logo yang } \\
\text { salah }\end{array}$ \\
\hline 11 & Color Palette & Warna dalam logo \\
\hline 12 & Typhography & $\begin{array}{c}\text { Font yang digunakan } \\
\text { sebagai logotype }\end{array}$ \\
\hline 13 & Pattern & Elemen visual \\
\hline 14 & Photography & Hasil foto produk \\
\hline 17 & Layouting Camera & $\begin{array}{l}\text { Posisi kamera dan } \\
\text { lighthing }\end{array}$ \\
\hline $18-25$ & Corporate Identity & $\begin{array}{l}\text { Penerapan logo pada } \\
\text { media pendukung }\end{array}$ \\
\hline
\end{tabular}

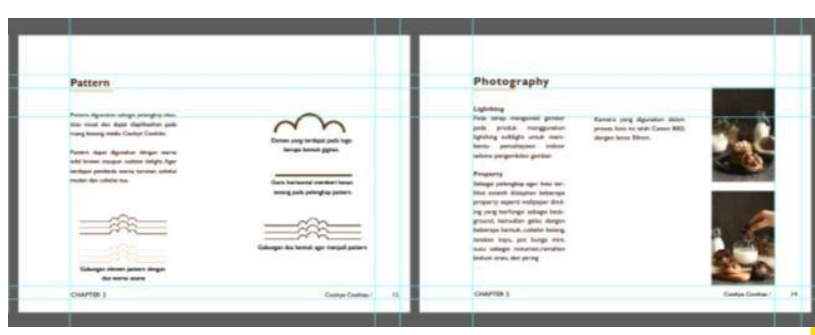


Gambar 19. Layout CIS

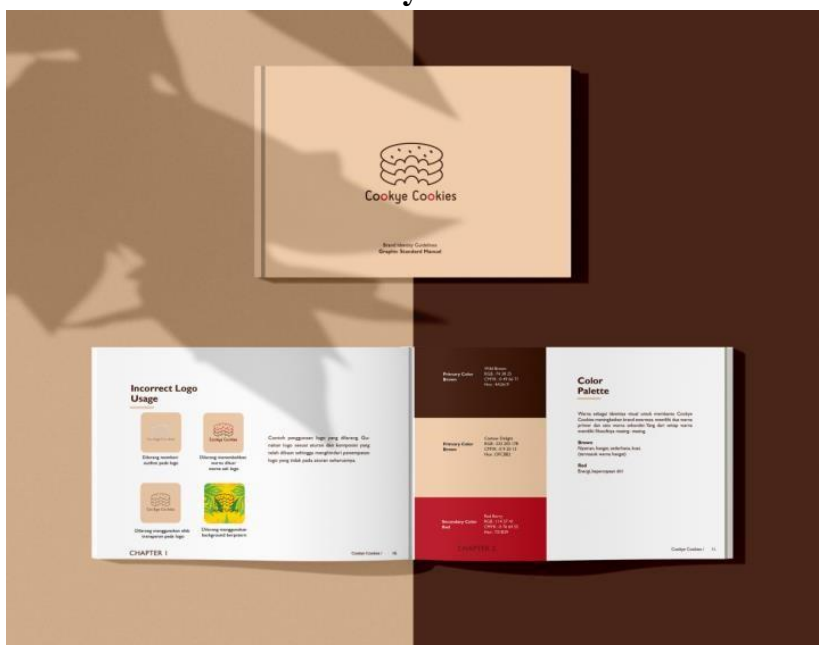

Gambar 20. Mock Up buku

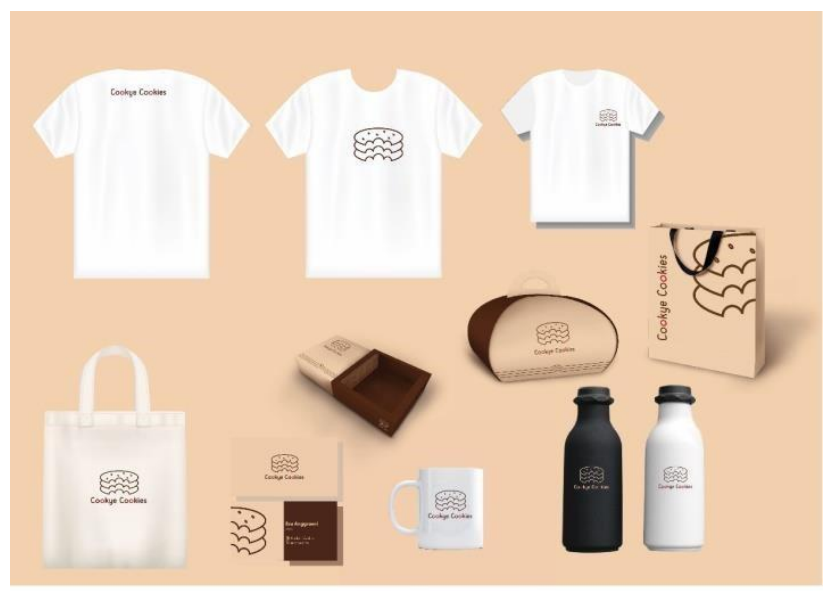

Gambar 21. Corporate Identiy

\subsection{Foto}
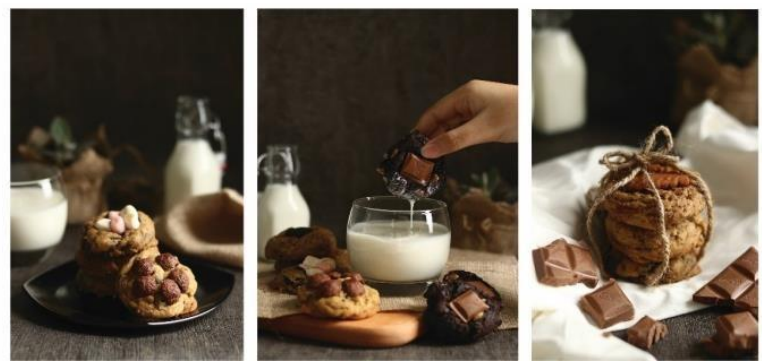

Gambar 22. Foto Produk

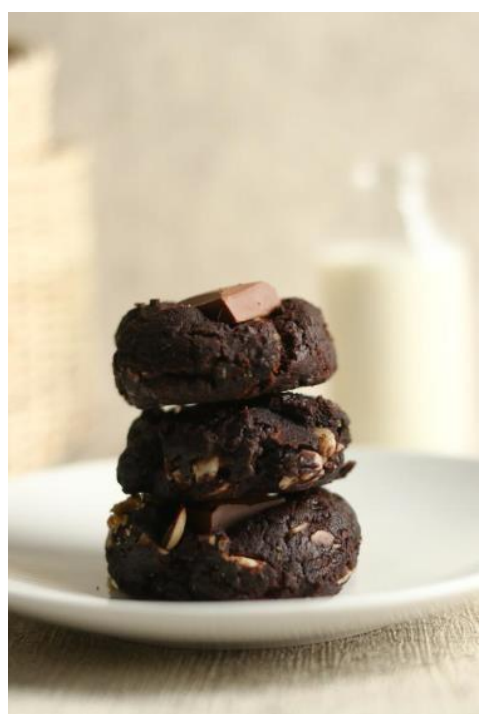

Gambar 23. Foto Produk

\section{Editing}

Setelah melalui tahap pengambilan gambar kemudian tahap selanjutnya ialah editing foto agar hasil lebih maksimal. Proses editing menggunakan aplikasi Adobe Lightroom.

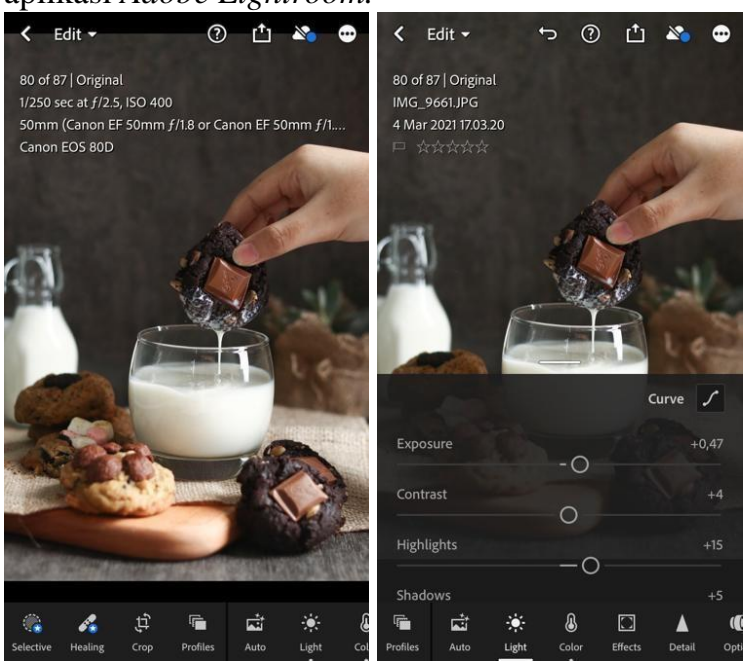

Gambar 24. Editing

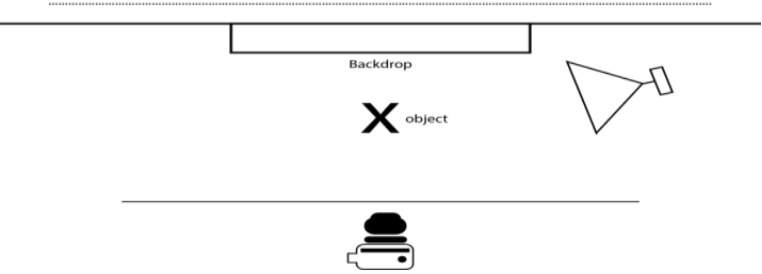

Gambar 25. Layout Kamera

\subsubsection{Feed Instagram}

Sebagai media promosi online Instagram dan fotografi merupakan hal yang penting sebagai upaya meningkatkan penjualan secara online. 
Pengambilan foto yang estetik serta menonjolkan produk secara langsung akan memperngaruhi konsumen untuk membeli, Karena manusia lebih cenderung cepat menangkap visual.
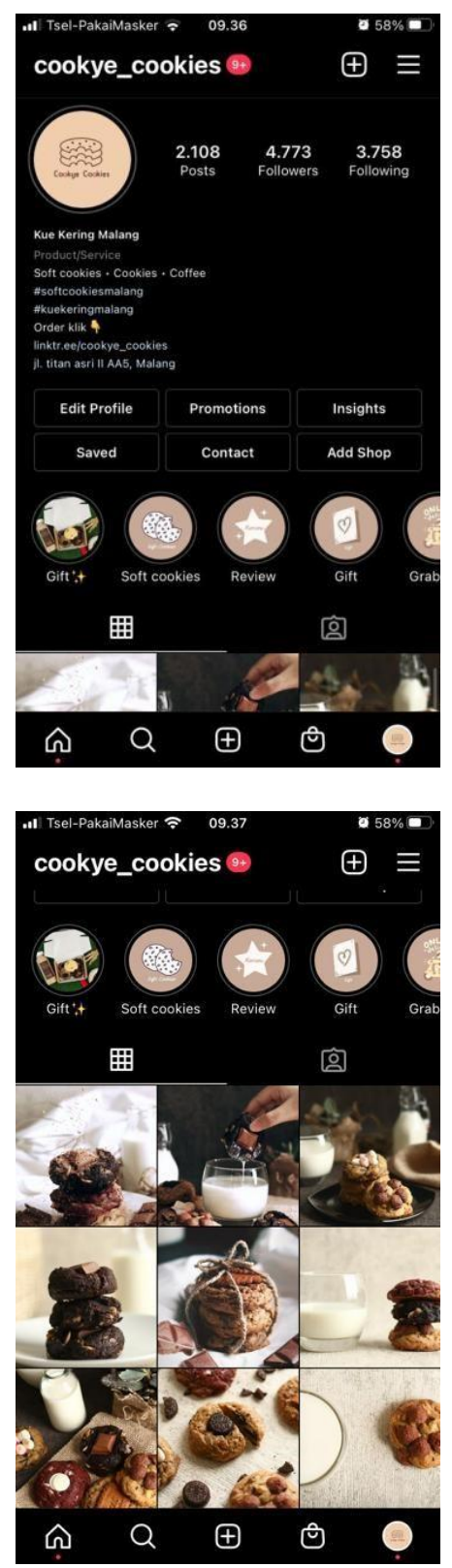

Gambar 26. Feed Instagram Cookye Cookies

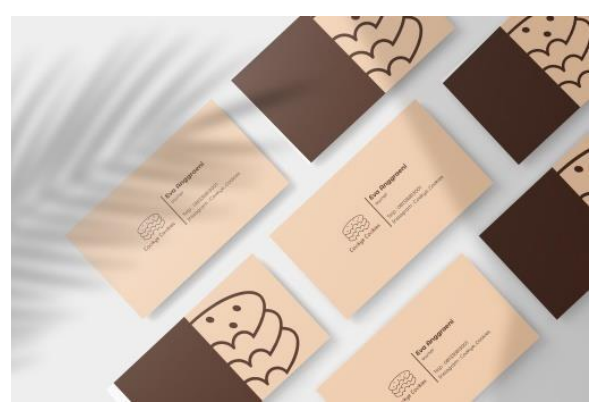

Gambar 27. Name Card

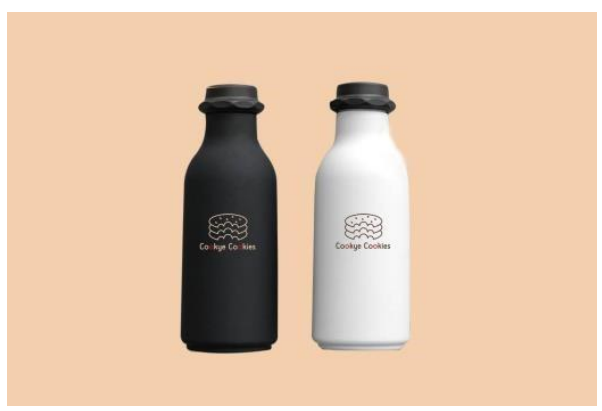

Gambar 28. Tumblr

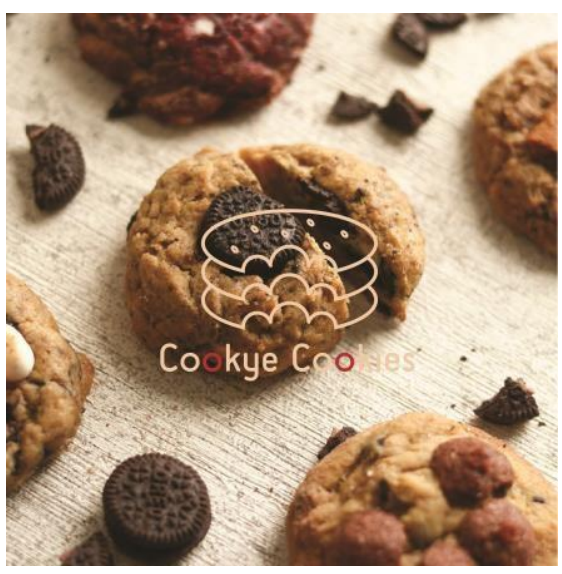

Gambar 29. Feed Instagram

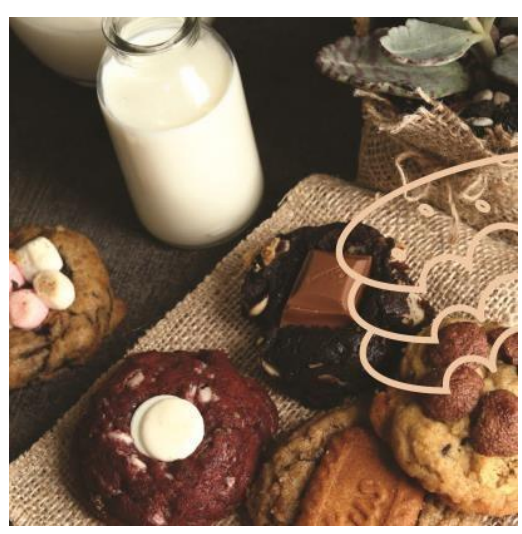

Gambar 30. Feed Instagram

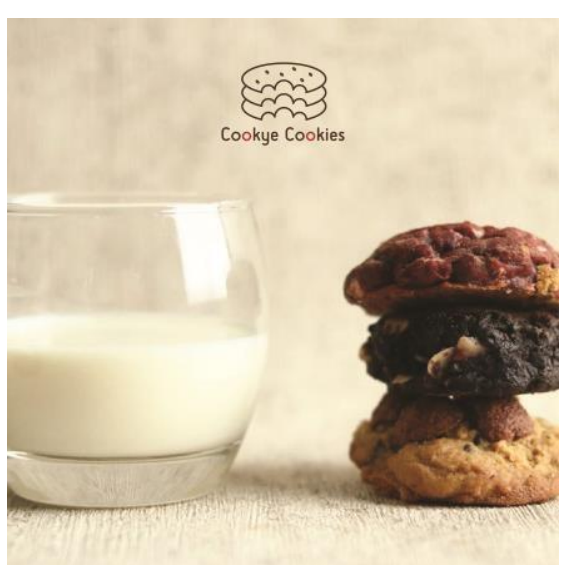




\section{Gambar 31. Feed Instagram KESIMPULAN DAN SARAN}

\subsection{Kesimpulan}

Menurut data yang telah ada perkembangan UMKM pada sektor makanan cukup meningkat pesat terutama di Kota Malang. Pertumbuhan sektor makanan dapat dilihat pada seluruh wilayah di kota mulai dari jajanan pinggir jalan hingga cafe yang mewah, mulai dari dengan harga kantong mahasiswa hingga kelas menengah keatas dapat dijumpau hampir diseluruh Kota Malang. Karena itu UMKM yang memilih sektor makanan pun semakin meningkat pula menjadi salah satu peluang bisnis yang cukup menjanjikan bai para pemula dalam hal berbisnis. Cookye Cookies merupakan salah satu usaha rumahan yang berada di Kota Malang dengan menjual dessert berupa cookies, dan soft cookies mengikuti trend yang tengah berkembang dimana dessert sudah banyak jenis dan macamnya. Namun kekurangan dari usaha ini ialah tidak memiliki identitas visual sebagai hal yang dapat mengenalkan produk pada masyarakat. Terbatasnya brand awareness terhadap produk Cookye Cookies membuat penjualan saat ini kurang meningkat. Dari hal tersebut dibutuhkan lah identitas visual yang harus dibentuk sebagai citra perusahaan dimulai dari visualisasi logo hingga desain kemasan. Dengan target konsumen pada usia 17-40 tahun dimana kebanyakan dari mereka menyukai mengirim hampers sebagai ucapan pada tiap perayaan hari besar atau mengirim sebagai hadiah ulangtahun. Sehingga penjualan dapat dilakukan melalui online. Pengambilan terhadap foto produk dapat menunjang meningkatnya penjualan karena memiliki konsep yang estetik.

Pada tahap perancangan ini menggunakan metode kualitatif sebagai langkah mengumpulkan data dengan langsung datang ke lapangan untuk menacri data-data yang dibutuhkan. Melakukan perancangan logo dan identitas visual lainnya. Pemahaman mengenai teori branding juga diperlukan sebagai acuan dalam proses perancangan.

\section{DAFTAR PUSTAKA}

Atsar, F. (2014). Persepsi dan Citra Identitas Visual Logo Bank Mandiri, Jurnal Itenas Rekarupa. No. 1, 2:11-18.

Christy, P dan Ellyawati, J. (2014), Pengaruh Desain Kemasan (packaging) pada Impulsive Buying. Jurnal Ekonomi Manajemen.P.1-14.

Firdausi, A.C. (7 Oktober 2019). Kutipan sumber internet dari https://jatimtimes.com/baca/202472/20191 007/194200/sektor-umkm-kota-malang-berhasil-bawapenghargaan-natamukti.

Mufreni, A. N .F. (2016). Pengaruh Desain Produk, Bentuk Kemasan dan Bahan Kimia Terhadap Minat Beli Konsumen (Studi KasusTeh Hijau Serbuk Tocha), Jurnal Ekonomi Manajemen. 49-52. observasi dan wawancara. Data yang telah terkumpul kemudian dianalisis menggunakan analisis SWOT. Pada data yang telah terkumpul ke tahap selanjutnya dilakukan brief untuk mendapatkan visualisasi yang diinginkan oleh perusahaan sehingga output yang dihasilkan lebih terarah dan tertata sesuai target pada perancangan.

\subsection{Saran}

\subsubsection{Bagi Pelaku Usaha}

Identitas visual adalah hal yang utama bagi sebuah perusahaan, bagaimana produk dapat dikenali dan dipasarkan jika kurang terdapat pesan yang akan disampaikan terhadap konsumen. Pembentukan identitas visual dan media promosi sebagai penguat brand yang telah ada sangat memiliki pengaruh dalam meningkatkan penjualan serta mengenalkan pada konsumen. Sehingga diharapkan Cookye Cookies dapat lebih aktif dalam media promosi sehingga terbentuklah interaksi terhadap konsumen.

\subsubsection{Bagi Peneliti Selanjutnya}

Konsep merupakan hal yang sangat dasar dalam pembentukan suatu identitas visual. Oleh karena itu sangat penting dalam menyiapkan data yang telah didukung dan konsep visual yang dapat menjadi pemecah permasalahan suatu perusahaan. Riset dan informasi yang lengkap untuk lebih memudahkan pada proses 
Trihendrawan,N.(19 Maret 2019).Kutipan sumber internet dari https://ekbis.sindonews.com/berita/ 1388028/34/sektor-kuliner-t.

Sasongko. (1 September 2018). Kutipan sumber dari https://malang.merdeka.com/kabar-malang/sutiajikulinersubsektor-ekonomi-kreatif-berpotensi-besar180912t.html.

Prawita, R., Swasty, W. dan Aditia, P. (2017).

Membangun Identitas Visual Untuk Media Promosi

Usaha Mikro Kecil dan Menangah. Jurnal Sosioteknologi.No:1, 16:28-34.

Mukhtar, S. dan Nurif, M. (2015). Perancangan Dalam Meningkatkan Hasil Produksi Terhadap Konsumen. Jurnal Sains Humanior. 181-185.

Nurfadilah, Putri Syifah. (29 Agustus 2018). Kutipan sumber dari https://ekonomi.kompas.com/read/2018/ 08/29/181946726/umkm-kuliner-tumbuh-suburberkatjasa-pengantaran-online. 